\title{
ANALISIS PEMANFAATAN OPENSOURCE DRONEDEPLOY DALAM PROSES MOZAIK FOTO UDARA (UAV)
}

\author{
Adkha Yulianandha Mabrur \\ Dosen Prodi Teknik Geodesi, Fak. Teknik Sipil dan Perencanaan ITN Malang \\ e-mail: adkha.yulianandha.mabrur@lecturer.itn.ac.id
}

\begin{abstract}
ABSTRAK
UAV (Unmanned Aerial Vehicle) merupakan salah satu perkembangan teknologi dalam bidang fotogrametri. Perkembangan teknologi UAV memberi dampak positif dalam bidang pemetaan secara efisien, cepat dan mencangkup kawasan yang luas. Salah satu wahana UAV yang digunakan dalam pemetaan adalah Drone. Beberapa vendor alat survey mengeluarkan software opensource secana online, hal ini sangat memudahkan bagi pengguna dalam pengolahan data foto. DroneDeploy adalah perusahaan yang membuat perangkat lunak berbasis cloud untuk pemetaan drone, sehingga memungkinkan untuk membuat peta udara dan model 3D dengan lebih mudah. Perangkat lunak DroneDeploy mengotomatiskan penerbangan drone dan membuatnya mudah untuk menangkap data udara dengan aplikasi seluler. Dengan kemudahan tersebut maka diperlukan suatu analisis tentang visualisasi hasil dari mozaik foto UAV menggunakan perangkat lunak tersebut dibandingkan dengan data citra satelit quickbird. Dalam hal ini Citra Quickbird berperan sebagai data acuan yang dianggap benar.
\end{abstract}

\section{Kata kunci : DroneDeploy, Foto Udara, Unmanned Aerial Vehicle (UAV), Quickbird}

\begin{abstract}
UAV (Unmanned Aerial Vehicle) is one of the technological developments in the field of photogrammetry. The development of UAV technology has a positive impact in the field of mapping efficiently, quickly and covers a wide area. One of the UAV vehicles used in mapping is the Drone. Some survey tool vendors release open source software online, this makes it very easy for users to process photo data. DroneDeploy is a company that makes cloudbased software for mapping drones, making it possible to create aerial maps and 3D models more easily. The DroneDeploy software automates drone flights and makes it easy to capture aerial data with the mobile application. With this convenience, we need an analysis of the visualization of the results of UAV photo mosaics using the software compared to quickbird satellite image data. In
\end{abstract}

PAWON: Jurnal Arsitektur, Nomor -- Volume --, Bulan Tahun, ISSN 2597-7636 
this case the Quickbird Image acts as a reference data that is considered correct.

\section{Keywords : DroneDeploy, Photography, Unmanned Aerial Vehicle (UAV), Quickbird}

\section{PENDAHULUAN}

Teknologi fotogrametri semakin berkembang dengan diciptakannya metode dan berbagai software pendukung secara otomatis dari data foto udara, secara efektif dan efisien dengan memanfaatkan foto udara wahana Unmanned Aerial Vehicle (UAV). UAV atau kendaraan udara tanpa awak adalah salah satu teknologi yang sedang mengalami perkembangan yang pesat dan memiliki potensi yang sangat besar, baik untuk keperluan militer maupun kepentingan sipil. Contoh aplikasi yang dapat diimplementasikan pada UAV adalah untuk kebutuhan survey, patroli, deteksi tambang mineral, riset,fotografi, dan keperluan lain. Kelebihan dari UAV adalah dapat digunakan pada misi-misi berbahaya tanpa membahayakan pilot / manusia. Dalam bidang pemetaan UAV dimanfaatkan sebagai wahana dalam pengambilan data foto yang akan diolah menjadi peta foto. Salah satu UAV yang digunakan berupa Drone.

Drone mampu menghasilkan beberapa image yang dapat disesuaikan dengan luasan area dan tinggi terbang, hal tersebut tersebut tergantung dari skala dan resolusi yang diinginkan. Hasil dari data foto tersebut akan dilolah dengan menggunakan software, terdapat berbagai macam software yang menunjang dalam pengolahan data foto, salah satu software opensource yang dapat digunakan secara online yaitu DroneDeploy. Software tersebut merupakan salah satu software yang simple dan mudah dalam pengolahan data foto bahkan diklaim mampu mengolah ribuan foto seperti yang dikutip Amit Chowdhry (2017) dalam The Story Behind DroneDeploy And How It Built The Largest Drone Mapping Repository.

Berdasarkan pemanfaatan software DroneDeploy yang memberikan berbagai kemudahan, maka diperlukan suatu pengujian secara sederhana tentang hasil visualisasi Orthofoto yang dihasilkan dari pengolahan software tersebut. Hasil orthofoto tersebut akan dibandingkan dengan Citra Quickbird yang merupakan citra satelit resolusi tinggi dengan cara melakukan proses overlay.pengujian sederhana ini hanya sebatas pengujian secara visual tanpa memakai GCP dan ICP dimana overlay dilakukan dengan mentranformasikan koordinat dari foto yang disesuaikan dengan koordinat pada citra Quickbird. 


\section{TINJAUAN PUSTAKA}

Fotogrametri atau aerial surveying merupakan teknik pemetaan menggunakan wahana foto udara. Hasil pemetaan secara fotogrametrik berupa peta foto dan tidak dapat dijadikan dasar atau lampiran penerbitan peta. Pemetaan secara fotogrametrik tidak dapat lepas dari referensi pengukuran secara terestris, mulai dari penetapan ground controls (titik dasar kontrol) hingga kepada pengukuran batas tanah. Batas-batas tanah yang diidentifikasi pada peta foto harus diukur di lapangan secara terestris. Menurut Van Hoeve (1993) Fotogrametri adalah suatu metode atau cara untuk mengkonstruksikan bentuk, ukuran dan posisi pada suatu benda yang berdasarkan pemotretan tunggal maupun stereoskopik.

Lain Van Hoeve tahun 1993 di bukunya tertulis bahwa Fotogrametri adalah seni, ilmu dan teknologi untuk memperoleh informasi terpercaya tentang objek fisik dan lingkungan melalui proses perekaman, pengukuran, dan interpretasi gambaran fotografik, dan pola radiasi tenaga elektromagnetik yang terekam.
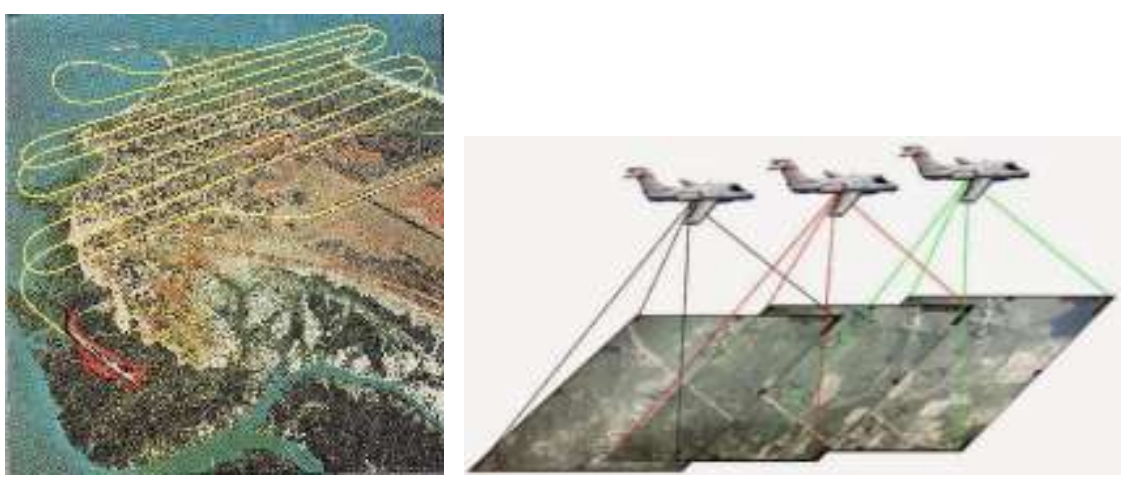

Gambar. 1

Aerial Surveying.

Sumber: Geomatics Training and Research Center

PAWON: Jurnal Arsitektur, Nomor -- Volume --, Bulan Tahun, ISSN 2597-7636 


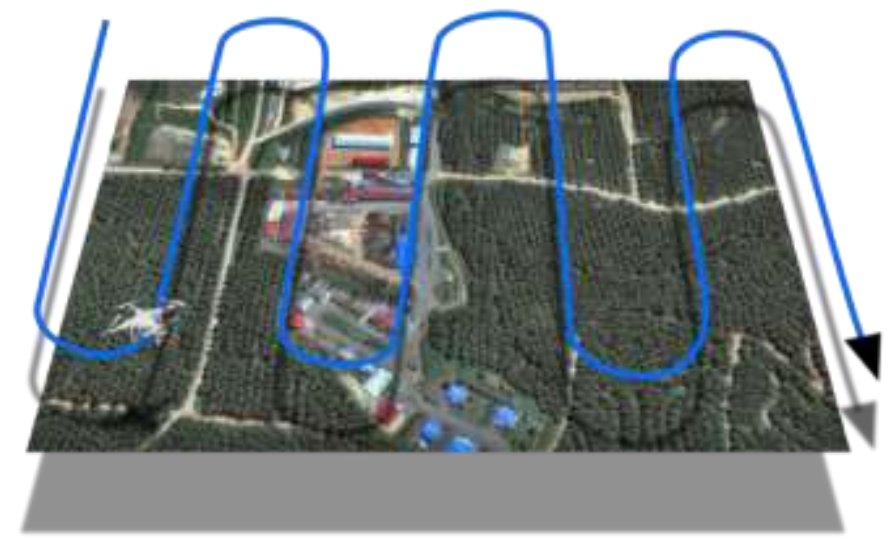

Gambar. 2

Jalur Terbang.

Sumber: Geomatics Training and Research Center

Secara umum, fotogrametri merupakan teknologi geo-informasi dengan memanfaatkan data geospasial yang diperoleh melalui pemotretan udara. Beberapa alasan untuk pemilihan penggunaan metode fotogrametri dibandingkan metode terestris, diantaranya:

1. Memiliki waktu yang relatif lebih cepat daripada metode terestris

2. Daya Jelajah yang lebih luas

3. Cost Operational yang lebih hemat

4. Data lebih sukar untuk dimanipulasi

Bahan dasar dalam pembuatan produk fotogrametris adalah beberapa kumpulan foto udara yang bertampalan (overlapping) yang diperoleh melalui pemotretan udara pada ketinggian tertentu.

\subsection{Unmanned Aerial Vehicle (UAV)}

Unmanned Aerial Vehicle (UAV) adalah salah satu jenis robot penjelajah udara tanpa awak. Unmanned Aerial Vehicle (UAV) juga sering disebut dengan nama Pesawat Udara Nir Awak (PUNA). UAV merupakan kendaraan udara tanpa awak (pilot pengendali) di dalamnya. Karena tidak memiliki awak, UAV harus dikendalikan dari jarak jauh menggunakan remote control dari luar kendaraan atau biasa disebut Remotely Piloted Vehicle (RPV). Selain itu, UAV juga dapat bergerak secara otomatis berdasarkan program yang sudah ditanamkan pada sistem komputernya.

Kelebihan utama dari UAV dibandingkan dengan pesawat berawak adalah bahwa UAV dapat digunakan pada situasi dengan resiko tinggi tanpa perlu membahayakan nyawa manusia, pada area yang tidak dapat diakses 
dan terbang pada ketinggian rendah dibawah awan sehingga foto yang dihasilkan terbebas dari awan. Selain itu, salah satu faktor kelebihan UAV adalah biaya. Harga perangkat UAV dan biaya operasionalnya jauh lebih murah jika dibandingkan dengan pesawat berawak. Dengan diimplementasikannya perangkat GPS/INS unit navigasi maupun stabilisasi memungkinkan kegiatan penerbangan yang presisi (sesuai dengan rencana terbang) sekaligus menjamin terpenuhinya cakupan area dan overlap foto yang diinginkan.

Keterbatasan dari UAV dibatasi oleh dimensi dari UAV itu sendiri. Karena dimensi UAV yang kecil membatasi kemampuan beban muatan yang dapat dibawa. Sehingga biasanya digunakan sensor atau perangkat kamera yang beratnya ringan berupa kamera format kecil. Karena format kecil ini tentunya bukan perangkat kamera dengan sensor yang dirancang untuk melakukan pemotretan udara secara akurat, sehingga menghasilkan kualitas gambar yang lebih rendah baik dari sisi resolusi, stabilitas dan tingkat akurasi. Selain itu daya jelajah dan tinggi terbang UAV juga terbatas karena kemampuan mesinnya yang memang tidak dirancang untuk terbang jarak jauh dan tinggi. Secara umum pembagian jenis UAV dilakukan menurut jenis, sumber tenaga pengerak dan besar atau berat pesawat.

1. Jenis pesawat UAV berdasarkan jenis sayap.

a. Fix wing: Pesawat model fixwing adalah pesawat yang memiliki bentuk sayap tetap atau tidak bergerak. Pesawat mendapatkan thrust dari gaya dorong motor yang menerpa bagian sayap yang memiliki bentuk airfoil tertentu dari depan sampai belakang sehingga menghasilkan gaya angkat.

b. Rotary wing: Pesawat model rotary wing memiliki sayap yang bergerak atau berputar atau baling-baling sehingga menghasilkan gaya angkat. Pergerakan pesawat diatur melalui perubahan sudut serang posisi baling-baling

2. Jenis pesawat berdasarkan sumber tenaga

a. Combustion engine. Sumber tenaga pesawat menggunakan pembakaran bahan bakar cair pada engine untuk menggerakkan propeler pesawat

b. Elcktric. Sumber tenaga pesawat menggunakan suplai daya dari baterai untuk menggerakkan propeler pesawat. Kekurangan pesawat jenis ini memiliki kecepatan standar, mengudara dalam waktu relatif singkat dengan daya jelajah menengah

3. Jenis UAV berdasarkan berat 
a. UAV super heavy adalah jenis UAV yang memiliki berat diatas $2000 \mathrm{Kg}$

b. UAV heavy adalah jenis robot penjelajah udara dengan berat antara $200-2000 \mathrm{Kg}$

c. UAV medium adalah robot penjelajah udara yang memiliki berat pada range $50-200 \mathrm{Kg}$

d. UAV light merupakan robot penjelajah udara dengan bobot 5$50 \mathrm{Kg}$.

e. UAV micro adalah robot penjelajah udara yang ringan dan memiliki bobot kurang dari $5 \mathrm{~kg}$

\subsection{Skala Foto Udara}

Skala dalam foto udara merupakan hasil perbandingan antara panjang fokus dengan tinggi terbang $(S=f / H)$. Bila pada bagian tepi sudah ada informasi skala dan panjang fokus, maka skala dapat dipakai untuk mengetahui ketinggian terbang saat melakukan pemotretan. Skala diperlukan untuk mengetahui jarak, luas, dan volume suatu objek yang tergambar pada foto udara. Skala yang tergambar pada foto udara biasanya berupa skala numerik. Skala tersebut masih sangat kasar karena tidak memperhatikan kondisi relief masing-masing tempat yang tergambar pada foto udara.

Foto udara mempunyai skala yang bervariasi, maka untuk membuat peta dengan skala dan geometri yang benar, foto udara tersebut harus diproses terlebih dahulu, disebut sebagai proses restitusi foto udara. Pengertian restitusi adalah mengembalikan posisi foto udara pada keadaan seperti pada saat pemotreatan dengan proses orientasi (orientasi dalam, relatif, absolut). Pada keadaan tersebut sinar-sinar yang membentuk objek secara geometris telah benar dan dapat dipakai untuk membuat peta dengan cara restitusi tunggal (rektifikasi) ataupun dengan cara restitusi stereo/orthofoto.

Skala foto udara adalah perbandingan jarak pada foto udara dengan jarak di permukaan bumi. Pada foto udara dikenal skala foto, yaitu skala rata-rata dari foto udara. Disebut skala rata-rata, karena sifat proyeksi pada foto udara adalah perspektif (sentral), berpusat pada titik utama (principal point). Dengan demikian skala di masing-masing titik tidak akan sama, kecuali bila foto udara tersebut benar-benar tegak dan keadaan permukaan tanah sangat datar. Besarnya skala rata-rata ditentukan oleh tinggi terbang dan tinggi permukaan bumi serta besar fokus kamera. Skala foto udara dapat dihitung dengan rumus : 


\section{$S=f / H$}

Dimana:

$S$ = Skala foto udara,

$\mathrm{f}=$ Panjang fokus,

$\mathrm{H} \quad=$ Tinggi terbang dari tempat yang dipotret

$$
S=d / D
$$

Dimana:

$$
\begin{aligned}
& S=\text { Skala foto } \\
& d=\text { Jarak di foto } \\
& D=\text { Jarak di lapangan }
\end{aligned}
$$

\subsection{Mozaik Foto}

Mozaik foto udara merupakan gabungan dari dua atau lebih foto udara yang saling bertampalan sehingga terbentuk paduan gambar yang berkesinambungan dan menampilkan daerah yang lebih luas (Wolf, 1983). Penggabungan dilakukan dengan memotong dan menyambungkan bagianbagian foto yang overlap atau sidelap. Mozaik udara umumnya dirakit dari foto udara vertical, namun kadang-kadang juga dirakit dari foto miring atau foto terestris. Jika dibuat dengan baik, akan memperlihatkan penampilan seperti suatu foto tunggal yang sangat besar.

Ditinjau dari teknik pembuatannya, Wolf (1983) menyebutkan ada tiga jenis mosaik, yaitu mosaik terkontrol, tidak terkontrol, dan semi terkontrol. Mosaik terkontrol adalah mosaik yang dibuat dari foto yang telah direktifikasi sehingga semua foto telah mempunyai skala yang sama. Mosaik tidak terkontrol adalah mosaik yang dibuat dari foto tegak yang belum direktifikasi serta belum diseragamkan skalanya. Mosaik semi terkontrol adalah mosaik yang disusun dengan menggunakan foto udara yang mempunyai beberapa titik kontrol, tetapi foto tersebut tidak terektifikasi dan mempunyai skala yang tidak seragam. 


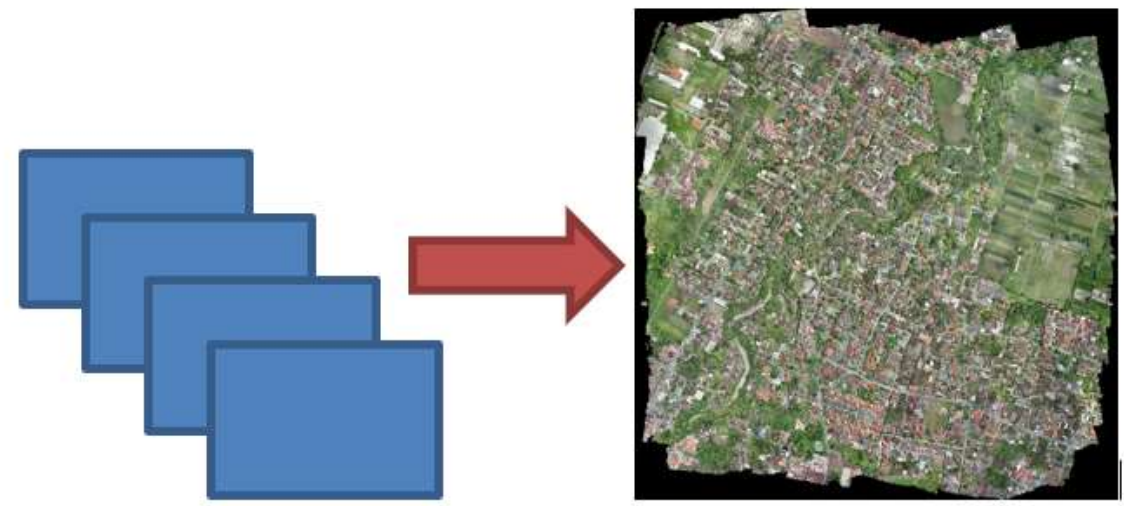

Gambar. 3

Mozaik Foto.

Sumber: Geomatics Training and Research Center

\subsection{DroneDeploy}

Aplikasi perangkat lunak DroneDeploy mengotomatiskan penerbangan drone dan juga membuatnya sangat mudah untuk menangkap gambar udara. Platform perangkat lunak DroneDeploy memproses gambar UAV menggunakan visi komputer mengubahnya menjadi $2 \mathrm{D}$, peta $3 \mathrm{D}$, model, dan banyak lagi.

Sejak 2013, platform perangkat lunak DroneDeploy telah memproses jutaan gambar dan membuat ribuan peta. Ini dianggap sebagai aplikasi dan platform pemetaan drone terkemuka yang tersedia. DroneDeploy menawarkan solusi untuk pertanian, pertambangan, konstruksi, aplikasi survei, dan perusahaan asuransi. Serta DroneDeploy baru-baru ini meluncurkan pasar aplikasi drone yang mengintegrasikan aplikasi pihak ketiga dengan mudah ke dalam alur kerja pelanggan, dan menyederhanakan kolaborasi dengan alat yang ada seperti Box, John Deere dan Autodesk. DroneDeploy saat ini memegang set data drone terbesar di dunia di lebih dari 20 juta hektar tanah di 160 negara dan 7 benua (Chowdhry, 2017).

\subsection{Citra Quickbird}

Quickbird merupakan satelit penginderaan jauh yang diluncurkan pada tanggal 18 Oktober 2001 di California, U.S.A. Dan mulai memproduksi data pada bulan Mei 2002. Quickbird diluncurkan dengan 98o orbit sunsynchronous dan misi pertama kali satelit ini adalah menampilkan citra 
digital resolusi tinggi untuk kebutuhan komersil yang berisi informasi geografi seperti sumber daya alam. Satelit Quickbird mampu untuk download citra dari stasiun three mid-latitude yaitu Jepang, Itali dan U.S (Colorado). Quickbird juga memperoleh data tutupan lahan atau kebutuhan lain untuk keperluan GIS berdasarkan kemampuan Quickbird untuk menyimpan data dalam ukuran besar dengan resolusi tertinggi dan medium-inclination, non polar orbit.

Setelah meng-orbit selama 90 hari, Quickbird akan memperoleh citra dengan nilai resolusi, Panchromatic sebesar $61 \mathrm{~cm}$ dan Multispectral sebesar 2.44 meter. Pada resolusi $61 \mathrm{~cm}$ bangunan, jembatan, jalan-jalan serta berbagai infrastruktur lain dapat terlihat secara detail. Quickbird dapat digunakan untuk berbagai aplikasi terutama dalam hal perolehan data yang memuat infrastruktur, sumber daya alam bahkan untuk keperluan pengelolaan tanah (manajemen, pajak). Sedangkan untuk keperluan industri, citra Quickbird dapat memperoleh cakupan daerah yang cukup luas sebesar $16.5 \mathrm{~km}$ atau $10.3 \mathrm{mil}$.

\section{METODE PENELITIAN}

Tahapan penelitian secara garis besar terdiri dari persiapan, pelaksanaan, pengumpulan data, pengolahan data, analisis data dan kesimpulan. Adapun tahapan-tahapan penting dalam penelitian dapat dilihat pada gambar diagram alir berikut ini

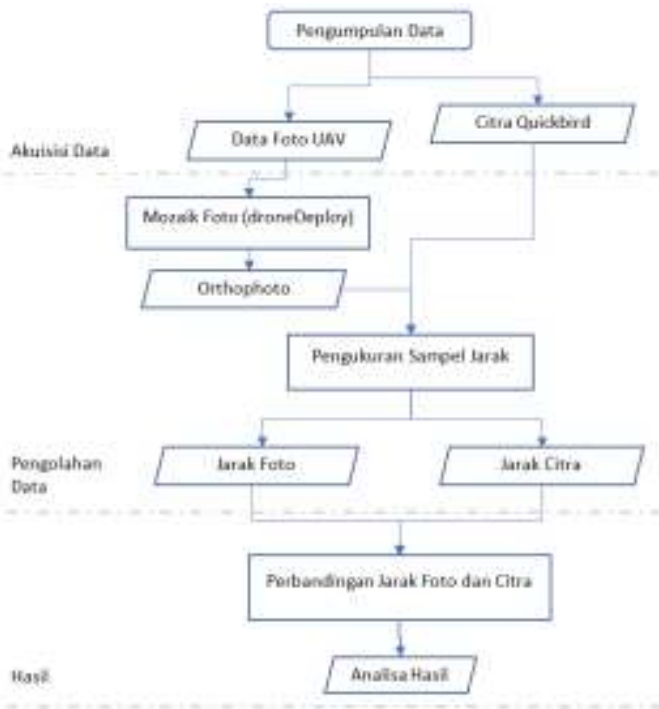

Gambar. 4

Diagram Penelitian. 


\section{HASIL DAN PEMBAHASAN}

Berdasarkan penelitian yang telah dilakukan, terdapat beberapa hasil dan pembahasan dari setiap proses yang dilakukan.

\subsection{Foto Udara UAV}

Hasil foto udara dengan wahana Drone DJI Phantom 3 Pro dengan objek daerah Kota Kediri, khususnya area pemantauan jalan. Dengan menggunakan tinggi terbang $65 \mathrm{~m}$, side dan front lap 40\% dengan jumlah foto yang dihasilkan sebanyak 237 buah. Data foto tersebut kemudian akan diolah dengan menggunakan software DroneDeploy secara online. Beberapa sampel hasil foto yang belum diolah seperti terlihat pada gambar 5.

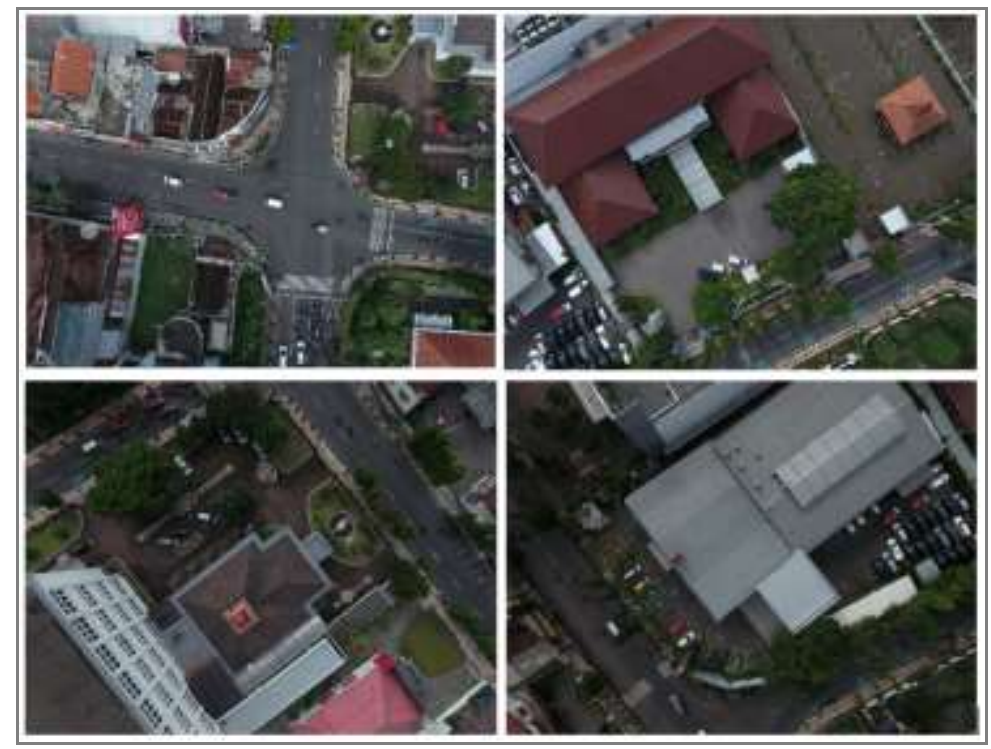

Gambar. 5

Hasil foto udara yang digunakan pembuatan orthofoto.

\subsection{Data Hasil Mozaik Foto (DroneDeploy)}

Hasil dari proses pengolahan menggunakan DroneDeploy berupa foto mozaik yang tersusun dari kumpulan beberapa foto. Terlihat pada gambar 6 dari hasil mozaik foto terlihat bagus secara visual. Hasil dari pengolahan software tersebut sangat dipengaruhi oleh beberapa factor seperti jumlah foto, tinggi terbang, dan prosentase overlay setiap lembar fotonya. Semakin rendah tinggi terbang akan memperjelas kenampakan objeck namun akan mengurangi cangkupan area, prosentase overlay juga menentukan jumlah

PAWON: Jurnal Arsitektur, Nomor -- Volume --, Bulan Tahun, ISSN 2597-7636 
foto yang akan dihasilkan dari pemotretan. Semakin besar prosentase akan semakin banyak foto yang akan dihasilkan maka akan semakin lama proses pengolahan. Karena ketelitian orthofoto sangat berpengaruh terhadap jumlah foto.

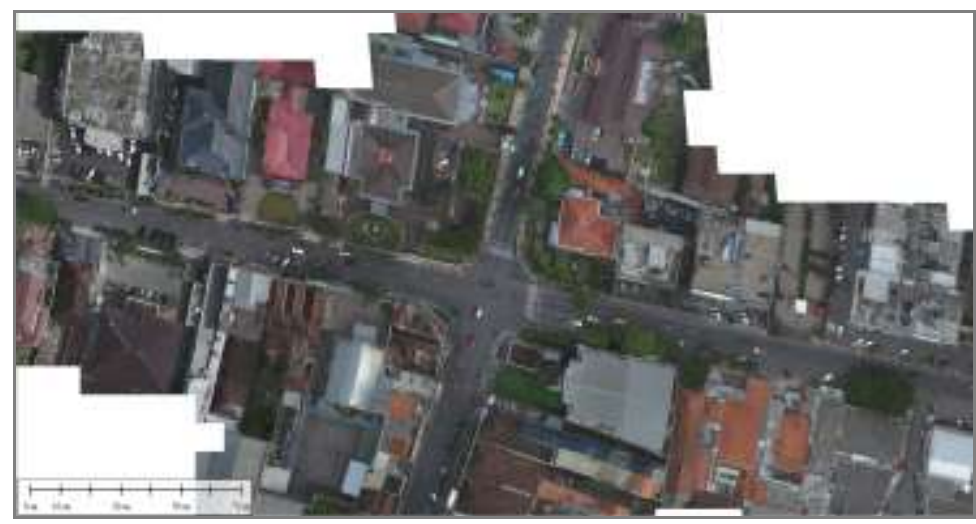

Gambar. 6

Hasil proses orthofoto.

Namun jika dilihat secara teliti ada beberapa area yang terlihat tidak presisi ketika proses mozaik foto seperti yang terlihat pada gambar 7. Hal ini biasanya dikarenakan pertampalan antar image yang kurang sesuai dikarenakan factor angin yang membuat getaran pada wahana dan juga biasanya terjadi di area-area ujung dari sebuah foto

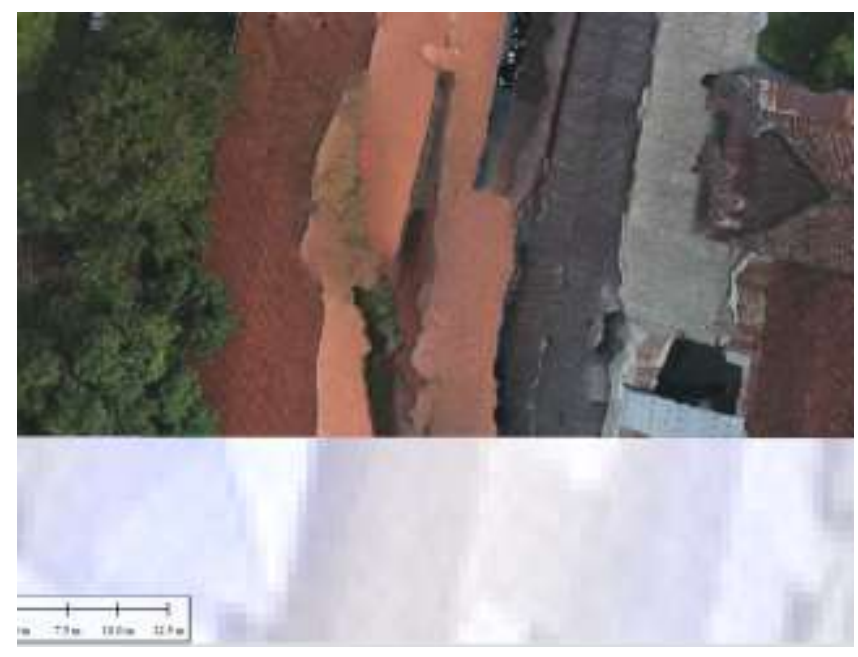

Gambar. 7

Area Overlay Kurang Presisi.

PAWON: Jurnal Arsitektur, Nomor -- Volume --, Bulan Tahun, ISSN 2597-7636 


\subsection{Hasil Perbandingan Jarak Foto dan Citra}

Hasil mozaik foto kemudian dilakukan proses orthorektifikasi dengan menggunakan koordinat pada citra Quickbird. Hasil orthofoto tersebut terlihat pada gambar 8. Secara visual orthofoto terlihat sesuai dengan citra Quicckbird.

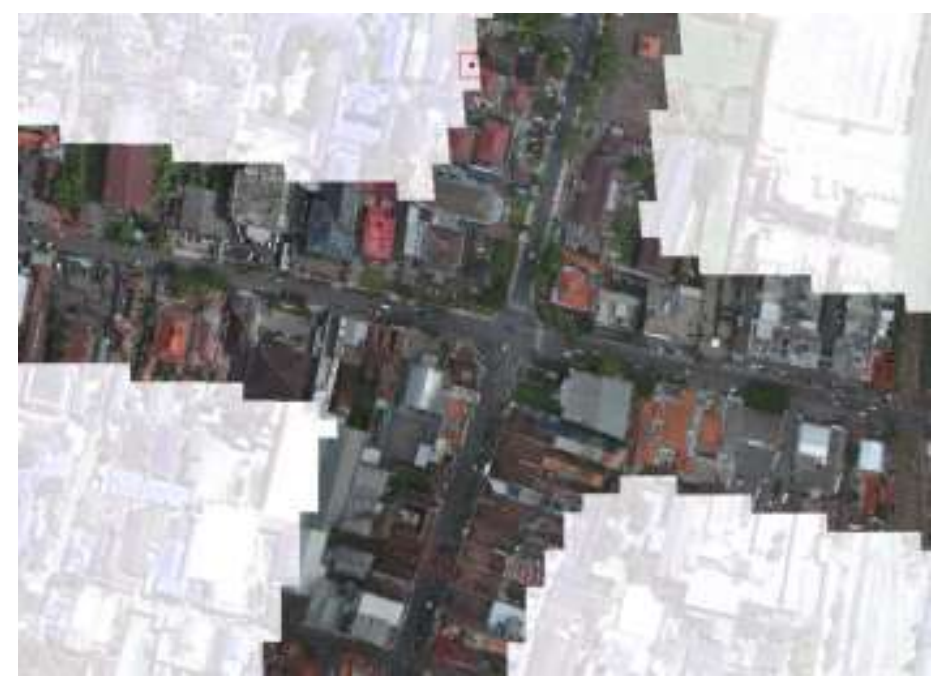

Gambar. 8

Posisi sampel Jarak Orthofoto dan Quickbird.

Selanjutnya dilakukan pengukuran sampel jarak sebanyak 8 buah dari masing-masing data.

Tabel 1.

Hasil perbandingan jarak

\begin{tabular}{|lrrr|}
\hline \multicolumn{4}{c}{ Jarak (m) } \\
\hline No. Sampel & \multicolumn{1}{c}{ Foto } & \multicolumn{1}{c|}{ Quickbird } & Selisih \\
\hline S1 & 81.83 & 80.5 & 1.33 \\
S2 & 36.2 & 36.04 & 0.16 \\
S3 & 7.18 & 7.6 & 0.42 \\
S4 & 10.85 & 10.68 & 0.17 \\
S5 & 22.86 & 22.89 & 0.03 \\
S6 & 20.2 & 20.34 & 0.14 \\
\hline
\end{tabular}

PAWON: Jurnal Arsitektur, Nomor -- Volume --, Bulan Tahun, ISSN 2597-7636 


\begin{tabular}{|lrrr|} 
S7 & 8.66 & 8.74 & 0.08 \\
S8 & 12.45 & 11.3 & 1.15 \\
\cline { 2 - 3 } & Selisih Rata-rata & & 0.2675 \\
\hline
\end{tabular}

Tabel 1 menunjukan hasil dari perhitungan selisih titik sampel antara jarak pada Orthofoto dan citra Quickbird. Dari 8 (delapan) sampel jarak yang diambil terdapat dua sampel yang memiliki nilai paling besar yaitu pada sampel 1 dan 8, hal ini dikarekan posisi sampel yang berada pada tepi orthophoto. Sedangkan dari ke enam sampel menunjukan nilai yang tidak terlalu besar. Hal ini berarti bahwa pengolahan foto UAV dengan menggunakan Dronedeploy sudah cukup bagus, namun untuk mendapatkan nilai ketelitian dan presisi dari orthofoto diharapkan menggunakan Ground Control Point (GCP) dan Independent Check Point (ICP).

\section{KESIMPULAN} berikut:

Dari penelitian yang dilakukan dapat diambil kesimpulan sebagai

1. Berdasarkan hasil pengolahan foto dengan menggunakan software opensource DroneDeploy secara visual terlihat cukup bagus dan software tersebut dapat menjadi alternatif pengolahan data foto dengan simpel dan cepat.

2. Efek mozaik foto pada orthofoto khususnya bagian tepi terlihat tidak sempurna hal ini berkaitan dengan persentase pertampalan setiap foto.

3. Hasil dari perbandingan data sampel antara Orthofoto dengan Citra Quickbird menunjukan selisih yang tidak terlalu besar, hal ini juga terlihat dari selisih nilai rata-rata yaitu $0.2675 \mathrm{~m}$

4. Ketelitian mengenai hasil dari pemanfaatan wahana Drone akan lebih akurat lagi jika menggunakan GCP dan ICP dengan membandingkan selisih jarak dan koordinat.

\section{DAFTAR PUSTAKA}

Akbar, Harmeydi. 2014. Pembuatan Peta Foto Dengan Foto Udara Format Kecil Di Kompleks Candi Prambanan Dengan Wahana Quadcopter.

Chowdhry, A. (2017). The Story Behind DroneDeploy And How It Built The Largest Drone Mapping Repository. www.forbes.com

FGDC. (2013). Geospatial Positioning Accuracy Standards, Part 3 : National Standart for Spatial Data Accuracy. 
Frianzah, A. 2009. Pembuatan Orthoimage dari Citra Alos Prism. Skripsi. Yogyakarta : Jurusan Teknik Geodesi FT.UGM.

Gularso, Herjuno. 2013. Tinjaun Pemotretan Udara Format Kecil Menggunakan Pesawat Model Skywalker 1680. Skripsi.

Hadi, B.S. 2007. Dasar-dasar Fotogrametri. Yogyakarta : Universitas Negeri Yogyakarta.

Ligterink, G. H. 1987. Dasar Fotogrametri Interpretasi Foto Udara. Jakarta: Universitas Indonesia.

Mills, J and Barber, D (2003) An Addendum to the Metric Survey Specifications for English Heritage the collection and archiving of point cloud data obtained by terrestrial laser scanning or other methods. Version 11/12/2003.

Purwadhi, F.S.H. 2001. Interpretasi Citra Digital. PT. Grasindo. Jakarta.

Santoso, B. 2004. Review Fotogrametri: Teknik Pengadaan Data dan Sistem Pemetaan. Program Megister Departemen Teknik Geodesi dan Geomatika ITB. Bandung.

Wikantika. K. 2009. Unmanned Mapping Technology: Development and Applications. Workshop Sehari "Unmanned Mapping Technology: Development and Applications" (UnMapTech2008). Bandung, Indonesia. 9 Juni 2008.

Wolf, Paul R. 1993. Element Fotogrametri Dengan Intepretasi Foto Udara dan Penginderaan Jauh, Edisi Kedua. Yogyakarta : Gadjah Mada University Press.

Surabaya. 